\title{
Mobilya sektöründe çalışan yöneticilerin öğrenen organizasyona ilişkin algıları
}

\section{A Perceptions of the Learning Organization of Managers of Employee in the Furniture Sector}

\author{
Nadir ERSEN ${ }^{1}$, Muhammet ARDIÇ리 illker AKYÜZ ${ }^{3}$, Hüseyin PEKER ${ }^{1}$, Selahattin BARDAK ${ }^{4}$ \\ ${ }^{1}$ Artvin Çoruh Üniversitesi, Orman Fakültesi, Orman Endüstri Mühendisliği Bölümü \\ ${ }^{2}$ Artvin Çoruh Üniversitesi, Artvin Meslek Yüksekokulu \\ ${ }^{3}$ Karadeniz Teknik Üniversitesi, Orman Fakültesi, Orman Endüstri Mühendisliği Bölümü \\ ${ }^{4}$ Sinop Üniversitesi, Mühendislik Mimarlık Fakültesi, Endüstri Mühendisliği Bölümü
}

\section{Özet}

Bu çalışmanın amacı mobilya sektörü alanında faaliyet gösteren işletmelerin üst ve orta kademe pozisyonlarında görev yapan kişilerin öğrenen organizasyon algılamalarını, işletmenin öğrenen organizasyona ne derece önem verdiğini belirleyebilmektir. Yöneticilerin öğrenen organizasyona ilişkin algıları, sürekli öğrenme, diyalogla öğrenme, takım halinde öğrenme, paylaşımcı sistemler, güçlendirilmiş personel, sistemler arası bağlantı ve liderlik olmak üzere yedi boyutta incelenmiştir. Araştırmada veri toplama yöntemi olarak anket tekniğinden yararlanılmış ve anket mobilya sektöründe faaliyet gösteren 13 işletmede çalışan 129 yöneticiye uygulanmıştır. Verilerin çözümlenmesinde, yüzde, frekans, Mann-Whitney U testi ve Kruskal Wallis testlerinden yararlanılmıştır. Araştırma sonuçlarına göre, mobilya sektöründe genel olarak öğrenen organizasyon kavramının uygulanmadığı ve yöneticilerin büyük çoğunluğunun öğrenen organizasyon kavramı hakkında bilgi sahibi olmadığı belirlenmiştir. Yöneticilerin öğrenen organizasyona ilişkin görüşleri yaş, gelir, eğitim, pozisyona ve görev süresine istatistiksel olarak anlamlı farklılık gösterirken, cinsiyete göre ise anlamlı bir farklılı̆ın olmadığı bulunmuştur.

Anahtar kelimeler: Mobilya sektörü, organizasyon, öğrenen organizasyon,

\section{Abstract}

In this study, aimed that were determined to businesses give much importance to the learning organization and learning organization perceptions of people which working at the upper and middle positions of enterprises in the furniture industry. It is examined that perceptions of the learning organization of managers in seven sizes including continuous learning, learning with dialogue, learning as a team, sharing systems, enhanced staff, links between systems and leadership. It was that benefits from survey method as the data collection method in research and conduct a questionnaire to 129 mangers in 13 companies in the furniture industry. It were used that percentage, frequency, Mann-Whitney $U$ and Kruskal-Wallis tests for analyze the data. According to the results, it were determined that do not apply the concept of organizational learning in the furniture industry and a great majority of managers haven't knowledge about the concept of learning organization. Mangers' opinions on the learning organization were found to be a statistically significant difference according to age, income, education, position and term of office except for gender.

Keywords: Furniture sector, learning organization, organization

\section{GíRiş}

Küreselleşme hızının arttığı günümüzde canlı varlıkların, değişen çevre koşullarında hayatlarını devam ettirebilmeleri, içinde bulundukları ortam şartlarına uyum sağlayabilme yeteneklerine bağlıdır. İşletmeleri de canlı birer varlık olarak düşünürsek, onların da yaşamlarını sürdürebilmeleri, sürekli değişen ve gelişen çevre koşullarına ve rekabet ortamına uyum sağlamakla mümkün olmaktadır. Özellikle son yüzyılda meydana gelen değişimler, önemli keşifler ve dünya pazarlarının birbirine yakınlaşması, mesafelerin kısalması bu değişimi daha hızlı ve daha zor yakalanılabilir bir hale getirmiştir. Küreselleşme sürecinde yaşanan ekonomik, teknolojik, kültürel, toplumsal, demografik gibi hızlı değişmeler, değişim ortamına ayak uydurabilmeleri için işletmeleri yeni 
yapılanmalara yöneltmekte ve ortaya koydukları farklılıklara bağlıdır (Çoban 2006; i̇star 2006). Bu noktada, 1990'lı yıllarda yönetim literatürüne damgası vuran ve çevresinde olan biten her şeyin farkında, işlerine bağlı, potansiyellerinin tamamını kullanabilmenin yollarını arayan, takım arkadaşlarıyla anlamlı bir hedefi ve vizyonu paylaşan bireylerden oluşan, öğrenmeyi teşvik eden, personelini geliştirmeyi, açık haberleşmeyi ve yapıcı diyaloğu ön plana çıkaran ve kendi geleceğini kendisi oluşturmak isteyen bir organizasyon yapısını benimseyen öğrenen organizasyon yaklaşımı karşımıza çıkmaktadır (Diken ve ark. 2006; Pelit ve ark. 2010).

Organizasyon, her fırsatta öğrenme yollarını aramakta ve müşterileri ile sürekli iletişim kurarak, onlarla arasında bir öğrenme/öğretme ilişkisi geliştirmektedir. Öğrenen organizasyonlar deneyler yaparak sürekli gelişme açık olduklarından, bilen, anlayan ve düşünen organizasyonlara göre değişime daha kolay uyum sağlayabilir. Yani değişimi bir olgu olarak algılamaktadır. Değişimi öğrenmek için bir fırsat olarak değerlendirir. Değişimi bir olgu olarak gören öğrenen organizasyon ile birçok araştırmacı kendi disiplinlerine uygun olarak çeşitli tanımlar yapmışlardır. Illk olarak öğrenen organizasyon Chris Argris ve D.A Schon tarafından, "hataların belirlenmesi ve düzeltilmesi" olarak tanımlanmıştır (Yazıcı 2008; Diker 2007; Tolgay 2010).

Senge'ye (2004) göre, “bütün fertleriyle gelişmeye, değişmeye ve rakiplerinden ileride olmaya inanmış, bunun için gerekli olan bilgiyi her zaman her yer ve her şart altında programlı bir biçimde kazanma becerisine sahip, yaratıcı ve daha geniş bir bakış açısı ile düşünen bireylerin oluşturduğu organizasyondur".

Garvin'e (1993) göre, “ Bilgiyi yaratma, edinme ve aktarma, yeni bilgi ve kavrayışları yansıtmak için davranışını değiştirme becerisine sahip örgüttür".
Braham (1998), öğrenen organizasyonu, “öğrenmeye öncelik veren”, Pedler ve diğerleri (1991) ise "tüm üyelerin öğrenmesini kolaylaştıran ve kendisini sürekli yenileyen organizasyon olarak tanımlamışlardır.

Öğrenen organizasyon ile ilgili yukarıda saydıklarımızın dışında birçok tanım mevcuttur. Sürekli gelişim, organizasyonel çapta öğrenme, işle paralel giden sürekli öğrenme, yenilik ve yaratıcılığa odaklanma, başarı için bilgi kaynaklarına ulaşma bilincine sahip olma ve bireysel ve grupsal öğrenmenin sürekli teşvik edilmesi gibi özellikleri taşıyan genel bir tanım yapılacak olursa, "Değişen çevre içerisinde daha iyi bir yönetim bilgisi için sürekli kendi kendin kendine dönüşümü gerçekleştiren ve bu amaçla teknoloji, güçlendirilmiş personel ve gelişmiş bir öğrenmeyi kullanarak daha iyi bir adaptasyon ve başarıyı elde eden organizasyonlardır" (Tuna ve Çakırer 2008).

Öğrenen organizasyon olabilmek örgütsel öğrenmenin ötesinde niteliklere sahip olmayı gerektirmektedir. Bunun için her biri ayrı ayrı önem taşıyan "kişisel hakimiyet, zihinsel model, paylaşılan vizyon, takım halinde öğrenme ve sistem düşünce" olmak üzere beş unsurun bir araya gelmesi gerekmektedir. Her unsurun hem ayrı ayrı hem de bir arada geliştirilmesi gerekmektedir. Bu unsurlar işletmede gerçekten öğrenen organizasyonun kurulmasında hayati bir boyutu sağlayacak ve kapasitelerini sürekli olarak artırmayı başaracaktır (Bulutlar, 2004; Senge 2004; Özus 2005).

Işletmelerin hayatta kalabilmeleri ve değişime ayak uydurabilmesi için son derece önemli olan öğrenen organizasyon ile ilgili araştırmaların ülkemizde 5-10 yıldan beri yapıldığı görülmektedir. Başta eğitim kurumları olmak üzere pek çok sektörde benzer araştırma çalışmalarının yapıldığı gözlemlenmiştir. Örnek vericek olursak; Toylan ve Göktepe (2010) "Öğrenen Organizasyon Olarak Üniversiteler: Türkiye'deki Bir Devlet Üniversitesinde Durum 
Analizi" adlı çalışmasında; Kırklareli Üniversitesi'nde görev yapan personelin öğrenen organizasyona ilişkin algılama düzeyleri saptamak ve bazı değişkenlere göre (görev süresi, cinsiyet) bu algıların farkıılaşıp farklılaşmadığı test edilmesi amaçlamıştır. Yumuşak ve Yıldız (2011) "Eğitim Örgütleri Öğrenen Organizasyon Özellikleri Göstermekte midir? Kamu ve Özel Illköğretim Okullarının Balıkesir illi Örneğinde Karşılaştırmalı Bir Analizi" isimli çalışmalarında; Balıkesir ilinde hizmet vermekte olan kamu ve özel ilköğretim kurumlarında görev yapan öğretmenlerin, öğrenen örgüte ilişkin algılarının ve bunu engelleyen örgütsel engellerin karşılaştırmalı bir analiz ile belirlenmeyi amaçlamıştır. Basım ve Arkadaşları (2009) "Öğrenen Örgüt Algısının Örgüt İçi Girişimciliğine Etkisi: Kamuda Bir Araştırma" adlı çalışmalarında; Ankara'da Bakanlıklara bağlı çeşitli kurumlarda görev yapan kamu çalışanlarının, görev yaptıkları kurumla ilgili öğrenen örgüt algılarının; yenilikçilik, risk alma ve fırsatlara odaklanma alt boyutları ile ele alınan örgüt içi girişimcilik tutumları ile ilişkisini araştırmıştır. Göztepe (2009) "Öğrenen Organizasyon Dinamiklerinin Toplam Kalite Yönetimi, Inovasyon ve Organizasyon Performansına Etkileri" adlı yüksek lisans tezinde; Gittikçe globalleşen dünyamızda iç ve dış rakipleriyle yarış durumunda olan işletmelerin iş hayatındaki devamlılıklarını sürdürebilmek için bireysel ve örgütsel öğrenmeye olan gereksinimlerinin ortaya çıkartılmasının gerektiğini vurgulamaya çalışmıştır. Güzelsoy (2010) "Organizasyonel Öğrenmenin Ürün İnovasyonu Üzerine Etkileri" isimli yüksek lisans tez çalışmasında; Bir firma bünyesindeki organizasyonel öğrenme kültürünün ürün inovasyon performansı üzerine etkilerini araştırmayı amaçlamıştır.

Fakat, mobilya sektörü alanında öğrenen organizasyon ile ilgili herhangi bir çalışma yapılmadığından bu konunun araştırılmasına ihtiyaç duyulmuştur. Bu vesile ile mobilya sektöründe görev yapan yöneticilerin öğrenen organizasyona ilişkin algılarının ne düzeyde, verdiği önemi ve yapılan diğer çalışmalar ile de karşılaştırılarak mobilya sektörünün, değişim çağı olarak adlandırılan bu dönemde değişime uyum ve değişimi yönetebilmek için ileri yönetim teknolojileri arasında gösterilen öğrenen organizasyon konusunda hangi aşamada olduğu belirlenmesi amaçlanmıştır.

\section{MATERYAL VE YÖNTEM}

Bu çalışmanın amacı, mobilya sektöründe faaliyet gösteren işletmelerdeki üst ve orta kademedeki yöneticilerin öğrenen organizasyon ilişkin algılarını tespit etmek ve derece önem verdiklerini belirlemektir. Ayrıca, bu genel amaç doğrultusunda cinsiyet, yaş, eğitim düzeyi, işletmedeki pozisyon ve işletmedeki görev süresine göre öğrenen organizasyona ilişkin algılarında bir farklılığın olup olmadığı tespit edilmeye çalışılmıştır.

Veri toplama aracı olarak yüz-yüze anket yöntemi kullanılmıştır. Hazırlanan anket, demografik özellikler ile öğrenen organizasyona ilişkin önermelerin yer aldığı iki bölümden oluşmaktadır. Birinci bölümde 11 soruluk kişisel bilgiler sorulmuştur. İkinci bölümündeki sorular Watkins ve Warsick (1997) tarafından geliştirilmiş olan Öğrenen Örgüt Modeli baz alınarak hazırlanmıştır. Bu modele göre öğrenen örgüt olma özellikleri, sürekli öğrenme, diyalog ve araştırma, takım halinde öğrenme, paylaşımcı sistemler, güçlendirilmiş çalışanlar, sistemler arası ilişki ve liderlik olmak üzere yedi ana başlıktan oluşmaktadır. Anketin ikinci bölümünde, sürekli öğrenme boyutunda yedi, güçlendirilmiş çalışanlar boyutunda beş ve diğer boyutlarda altışar soru olmak üzere toplam 42 soru bulunmakta ve 5'li Likert ölçeği kullanılmıştır. (1: Tamamen katılmıyorum, 2: Katılmıyorum, 3: Kararsızım, 4 Katılıyorum, 5: Tamamen katılıyorum)

Araştırma kapsamında ele alınacak firmaların belirlenmesinde, zaman ve sayı kısıtlayı ı 
faktörlerinden MOSDER 2006 verilerindeki işçi sayıları (300 ve üstü) esas alınmıştır. Fakat, bazı firmaların çalışanlarının zamanını alacağı, kurumsal bilgiyi firma dışına aktarmak istemedikleri ve çok yoğun olduklarını beyan ederek anket uygulama talebimiz ret edilmiş olup, onların yerine mobilya sektöründe faaliyet gösteren başka firmaları araştırma evreni kapsamına dahil edilmiştir. Araştırma mobilya sektöründe faaliyet gösteren 13 firmadaki üst ve orta kademedeki yöneticilere uygulanmıştır. 20 üst ve 109 orta kademe yönetici olmak üzere, toplam 129 kişi ankete cevap vermiştir. Araştırmada kullanılan anket formunun güvenilirlik analizi sonucu Cronbach Alpha değerleri 0.847 ile 0.919 arasında değişmektedir. Verilerin analizi ise SPSS 16.0 for Windows istatistik programıyla yapılmıştır. Verilerin analizinde, iki değişkenin olduğu durumlarda bağımsız örneklemler için Mann-Whitney $U$ testi ve ikiden fazla değişkenin olduğu durumlarda ise Kruskal Wallis analizi kullanılmıştır.

\section{BULGULAR VE TARTIŞMA}

\section{Katılımcıların Sosyo-Demografik Özellikleri}

Araştırmaya katılanların \%24'ü kadın \%76'sı erkektir. Anketi yanıtlayan mobilya sektörü çalışanlarının \%42.8'sı 26-33 yaşları arasında, \%32.6'sı 34-41 yaşları arasında, \%14.7'si 42 yaş ve üzeri yaşlarında ve \%10.1'i 18-25 yaşları arasındadır. Araştırmaya katılan çalışanların ağırıklı olarak üniversite mezunu olduğu görülmektedir. Ankete katılan çalışanların $\% 15.5^{\prime}$ ini üst düzey yöneticiler, $\% 84.5$ 'ini orta düzey yöneticiler oluşturmaktadır. Ankete katılanların büyük çoğunluğu 3000 TL ve altında ücret aldığı görülmektedir. Çalışanların \%50.4'ü 05 yıl arasında \%20.2'si 6-10 yıl ve 11-15 yıl arasında, \%9.3'ü 15 yıl ve üzerinde mevcut işletmede çalışmaktadır. Katılımcıların yaklaşık \%40' । 0-5 yıl arasında mobilya sektöründe faaliyet gösteren bir işletmede çalıştığını söylemiştir.
İ̧̧letmelerin yaklaşık olarak \%40'ında öğrenen organizasyon kavramı uygulanmaktadır. Ankete katılanların yaklaşık \%70'i ise öğrenen organizasyon kavramının ne demek olduğu hakkında bilgi sahibi değildir.

\section{Yöneticilerin Öğrenen Organizasyona İlişkin Algıları}

Çizelge 1'de mobilya sektöründe faaliyet gösteren işletmelerin üst ve orta kademedeki yöneticilerin öğrenen organizasyon ilişkin algıları yedi boyutta incelenmiş ve görüşlerinin yüzde, frekans, aritmetik ortalama ve standart sapma değerleri verilmiştir.

"Sürekli öğrenme" boyutu ile ilgili verilen cevapların ortalamasına bakıldığında, çok yüksek olmamakla birlikte mobilya sektöründe çalışanların kişisel gelişimleri için öğrenmelerini destekleyici bir yönetim sergilendiği (Ort= 3.56), mobilya işletmelerinde öğrenmeyi teşvik edici bir ödül sisteminin olamaması (Ort=3.26) ve hataların ders alma ve öğrenmeyi artırmak için açıklıkla dile getirilmesinin düşük oranda olduğu önemli bir veridir (Ort=3.45). Fakat mobilya işletmelerinde çalışan kişilerin öğrenme konusunda sürekli birbirine destek olduğu (Ort= 3.77) belirlenmiştir.

"Diyalogla öğrenme" boyutu ile ilgili cevapların ortalamasına bakıldığında mobilya işletmelerinde çalışanların farklı fikirlere açık olduğu, fikirlerini açıkça belirtebildiği güvene dayalı bir ortamın olduğu sonucuna varılmaktadır (Ort=3.69). Özellikle mobilya işletmelerinde çalışanların birbirine karşı saygılı olmasına yönelik algının (Ort=3.97) yüksek olması, yeri geldiğinde "neden" sorusunun kolayca sorulabildiğini (Ort=3.70) ve karşılıklı bilgi alış verişinin (Ort=3.66) yüksek olduğu görülmektedir. Ancak mobilya sektörü çalışanlarının birbirine karşı dürüstlük ve geri besleme konusunda (Ort=3.58) düşük düzeyde olduğu sonucuna varılmıştır. 
Çizelge 1. Yöneticilerin öğrenen organizasyona ilişkin algılarının analizi

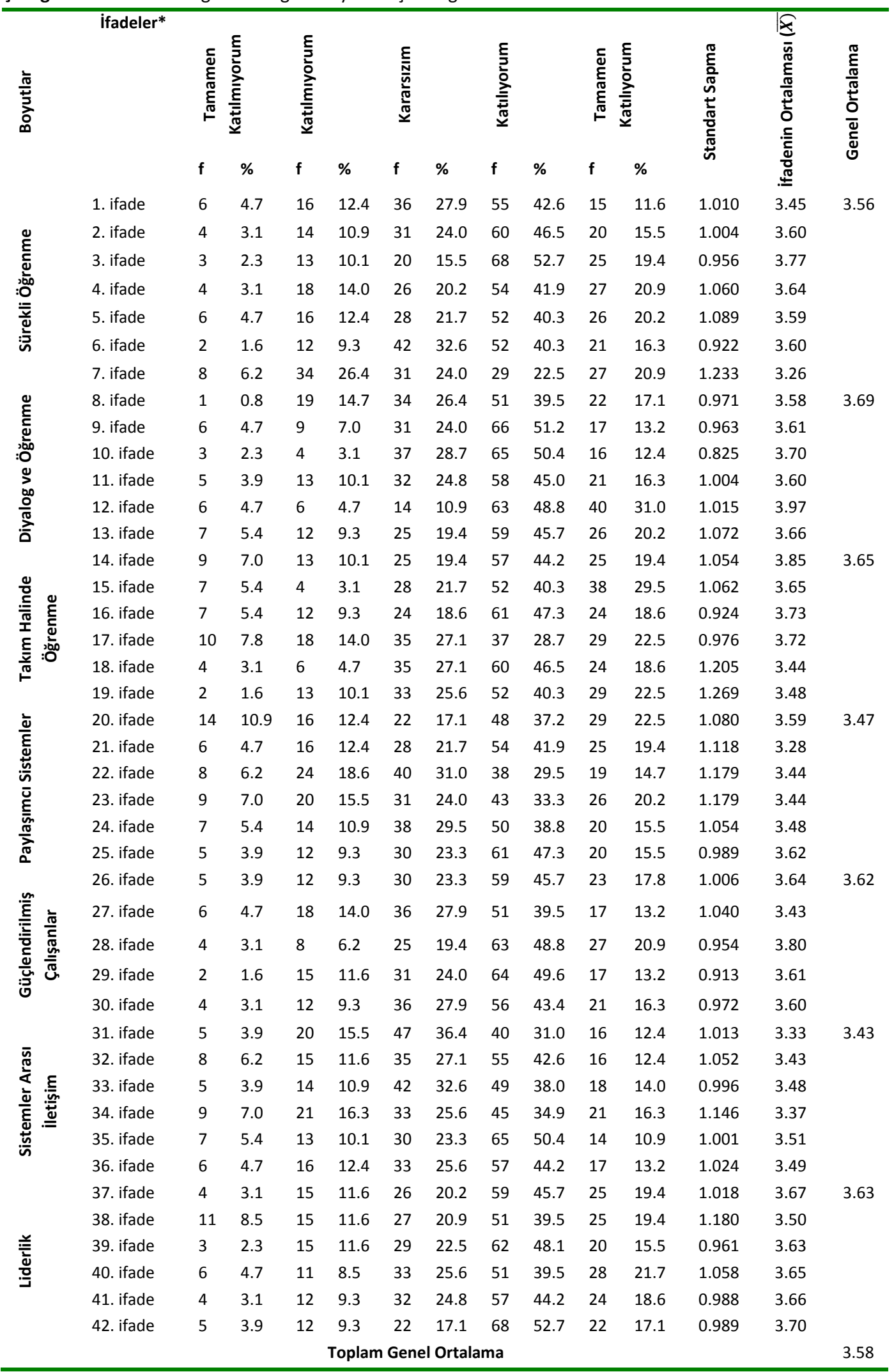

*ifadelerin tümü ekte yer almaktadır.

"Takım halinde öğrenme" boyutu ise ortalamanın çalışmalarını konusunda birlikte hareket üzerinde bir sonuç vermiştir (Ort=3.65). Mobilya etmelerine rağmen, çalışanların aldıkları başarılar sektöründe çalışanların, bireysel ve bölüm sonucunda ödüllendirilmediklerini $(O r t=3.44)$ ve 
önerilerinin örgüt yönetimindeki kişilerin tarafından pek dikkate alınmadığını (Ort=3.48) düşünmektedirler.

Mobilya sektöründe faaliyet gösteren işletmelerde, öğrenme için harcanan kaynaklar ve zaman hususunda bir değerlendirme yapılmasına (Ort=3.62) rağmen öğrenen organizasyon olma yolunda "Paylaşımcı sistemler" boyutunun düşük olduğu belirlenmiştir. Bunun nedeni, işletmede çalışan kişilerin ihtiyaç duyduğu bir bilgiye yavaş ve zor ulaşmasından (Ort=3.28) kaynaklanmaktadır.

Mobilya işletmelerinde çalışanların güçlendirilmiş çalışan olabilmesi için mobilya işletmelerinin, çalışanların işletme vizyonu oluşturulurken katkıda bulunmasına teşvik etmek (Ort=3.80) ve çalışanların insiyatif almasına olanak sağladığı (Ort=3.64) görülmektedir.

Çalışanların probleminin çözülmesi konusunda tüm işletme içinden cevap alması konusunda yönlendirilmediği ve desteklenmediği (Ort=3.49), işletme içinde alınan kararlarda çalışanların moralinin nasıl olacağı gözetilmeden (Ort= 3.37) karar alındığı, iş ve aile arasında denge sağlanamadığından (Ort=3.33) ve çalışanların dar bir perspektifle düşünmesini sağladığından (Ort= 3.43) dolayı "Sistemler arası iletişim" boyutu mobilya sektöründe oldukça düşük olduğu görülmektedir.

"Destekleyici liderlik" boyutu da ortalamanın üzerinde bir sonuç vermiştir (Ort=3.63). Mobilya işletmelerinde, yönetimin öğreneme ve gelişim için çalışanlardan gelen talepleri desteklemeleri, (Ort=3.67), ortak vizyonun gerçekleştirilmesi için çalışanlarında katılmasına imkan sağlanması (Ort=3.65), yönetimin öğrenme konusunda olası fırsatlar konusunda çaba içinde olması ve gerçekleştirilen faaliyetlerin değerlerle uyumlaştırılması (Ort=3.70) destekleyici liderliğin var olduğunu her ne kadar gösterse de, işletme hedefleri ve gelecek planları hakkında güncel bilgilerinin paylaşılması (Ort=3.50) hususunda ortalamanın altında kalmaktadır.

Yöneticilerin Demografik Özelliklerine Göre Öğrenen Organizasyona iliş̧kin Algılarının İstatistiksel Analizi

Mobilya sektöründe faaliyet gösteren işletme yöneticilerinin cinsiyet, yaş, gelir durumu, eğitim düzeyi, işletmedeki pozisyonu ve görev süreleri itibariyle öğrenen organizasyona ilişkin algıları arasında anlamlı bir farklılık olup olmadığı belirlenmeye çalışmıştır. Yöneticilerin öğrenen organizasyona ilişkin görüşlerinin, cinsiyet ve işletmedeki pozisyona göre farklılığın belirlenmesinde Mann-Whitney $U$ testi ve yaş, gelir durumu, eğitim düzeyi ve görev sürelerine göre farklılık olup olmadığının belirlenmesinde ise Kruskal-Wallis analizi kullanılmıştır.

Yöneticilerin cinsiyeti ile öğrenen organizasyona ilişkin algıları arasında anlamlı bir farklılık olup olmadığı ile ilgili yapılan analiz sonucunda çıkan veriler aşağıdaki gibidir; Çalışanların sürekli öğrenmeye ilişkin algıları p>0.05 (0.095), diyalog ile öğrenme hususundaki algıları p>0.05 (0.508), takım halinde öğrenmeye ilişkin algıları $p>0.05$ (0.374), paylaşımcı sistemlere ilişkin algıları p>0.05 (0.815), güçlendirilmiş çalışanlar ile ilgili görüşleri $p>0.05$ (0.375), sistemler arası bağlantıyla ilgili algıları $p>0.05$ (0.494) ve destekleyici liderlik boyutu ile ilgili algıları $p>0.05$ (0.760) olduğundan yöneticilerin cinsiyeti ile öğrenen organizasyona yönelik algıları arasında istatistiksel olarak anlamlı bir farklılık bulunmamaktadır.

Yaş grubuna göre; sürekli öğrenme boyutu $p>0.05$ (0.137), takım halinde öğrenme boyutu $p>0.05$ (0.181), paylaşımcı sistemler boyutu $p>0.05$ (0.251), güçlendirilmiş çalışanlar boyutu $p>0.05$ (0.077) ve sistemler arası iletişim boyutu p>0.05'ten (0.613) büyük olduğu için gruplar arasında anlamlı bir farklılık yoktur. Ortalamaları dikkate alındığında, paylaşımcı sistemler hariç diğer öğrenen organizasyon boyutlarında 42 ve üstü yaş grubunun ortalaması daha yüksek olsa 
da bu fark istatistiksel olarak anlamlı bir fark değildir. Ayrıca, $p<0.05$ 'ten küçük olduğundan yöneticilerin yaşları ile diyalog ile öğrenme boyut ve destekleyici liderlik boyutuna ilişkin görüşleri arasında anlamlı bir farklılık olduğu görülmektedir.

Mobilya sektöründe çalışan yöneticilerin işletmede bulundukları pozisyon ile öğrenen organizasyon boyutları arasında istatistiksel olarak anlamlı bir farklıık bulunmaktadır $(p<0.05)$. Yani üst kademe yöneticilerin öğrenen organizasyon boyutları ile ilgili sorulara verdikleri cevapların aritmetik ortalaması, orta kademedeki yöneticilere göre daha yüksek çıkmıştır.

Yöneticilerin gelir durumları ile sürekli öğrenme boyutu ( $p=0.106)$ ve diyalogla öğrenme boyutu $(p=0.393)$ arasında anlamlı bir farklılık yoktur $(p>0.05)$. Fakat takım halinde öğrenme boyutu $(p=0.008)$, paylaşımcı sistemler boyutu $(p=0.001)$, güçlendirilmiş çalışanlar boyutu $(p=0.000)$, sistemler arası iletişim $(p=0.000)$ ve destekleyici liderlik boyutları $(p=0.013)$ ile gelir arasında istatistiksel olarak anlamlı bir fark bulunmuştur $(p<0.05)$. Öğrenen organizasyon boyutlarının hepsinde genellikle 4001-5000 TL gelire sahip yöneticilerin görüşlerinin ortalaması daha yüksektir.

Eğitim düzeyine göre, öğrenen organizasyon boyutları $\mathrm{p}=0.000$ olduğu için gruplar arasında \%0.1 anlamlılık düzeyinde istatistiksel olarak bir farklılık ortaya çıkmaktadır. Eğitim düzeyi arttıkça öğrenen organizasyona ilişkin algılarının değeri de artmaktadır.

Üst ve orta kademedeki yöneticilerin görev süresi ile sistemler arası iletişim boyutu $p>0.05$ (0.090) arasında anlamlı bir fark bulunmuyor iken, diğer öğrenen organizasyon boyutları arasında istatistiksel olarak anlamlı bir farklılık görülmektedir. Çalışanların görev süreleri ile öğrenen organizasyona ilişkin algıları arasındaki incelemeyle ilgili yapılan analiz sonucunda, yöneticilerin öğrenen organizasyona ilişkin sorulara verdikleri cevaplarının ortalaması en yüksek 11-15 yıl çalışan yöneticilerde olduğu görülmektedir.

\section{SONUÇLAR}

Teknoloji, ürün ve rekabet koşullarının sürekli değişip yenilendiği günümüzde her işletme ve kurumlarda olduğu gibi mobilya sektöründe faaliyet gösteren işletmelerin hayatta kalmaları için bu şartlara uyum sağlaması gerekmektedir. Bunun için de çevre şartlarını çok iyi tanımalı, analiz edebilmeli ve değişimleri takip edebilmelidir. Değişimlerin takibi hususunda işletmelere yardımcı olan süreçlerden biri de organizasyonel öğrenmedir ve rekabet yarışında hayatta kalan kurumlar incelendiğinde öğrenen organizasyon kavramına son derece önem verdiği görülmektedir. Yapılan bu çalışma ile orman ürünleri sanayi içinde bulunan diğer sektörler de uygulanması konusunda fayda sağlayacaktır.

Araştırma sonucu mobilya sektöründe faaliyet gösteren işletmelerin üst ve orta kademe yöneticilerinin öğrenen organizasyona ilişkin algıları "sürekli öğrenme, diyalogla öğrenme, takım halinde öğrenme ortak vizyon, paylaşımcı sistemler, sistemler arası bağlantı ve liderlik olmak üzere yedi boyutta incelenmiş ve analiz edilmiştir. Yapılan anket sonucu genel olarak öğrenen organizasyona ilişkin algılarının değeri orta düzeyde (Ort=3.60) bulunmuştur. Yani mobilya sektöründe faaliyet gösteren işletmelerin öğrenen organizasyon kavramına yeterince önem vermemektedir. Her ne kadar öğrenen organizasyon algı değeri orta düzeyde bulunsa da, mobilya sektöründe çalışanların birbirine karşı oldukça saygılı olduğu belirlenmiştir. Fakat öğrenme konusunda teşvik edici bir ödüllendirme sisteminin olmaması (Ort=3.26) oldukça düşüktür. 
Çizelge 2. Yöneticilerin demografik özelliklerine göre öğrenen organizasyona ilişkin algılarının istatistiksel analiz sonuçları

\begin{tabular}{|c|c|c|c|c|c|c|c|c|c|c|c|c|c|c|c|c|c|}
\hline \multicolumn{2}{|c|}{ Demografik Özellikler } & \multicolumn{16}{|c|}{ Öğrenen Organizasyon Boyutları } \\
\hline & & \multicolumn{4}{|c|}{ Sürekli Öğrenme } & \multicolumn{4}{|c|}{ Diyalogla Öğrenme } & \multicolumn{4}{|c|}{ Takım Halinde Öğrenme } & \multicolumn{4}{|c|}{ Paylaşımcı Sistemler } \\
\hline & & $\bar{X}$ & $x^{2}$ & $\mathbf{u}$ & $\mathbf{P}$ & $\bar{X}$ & $x^{2}$ & $\mathbf{u}$ & $\mathbf{P}$ & $\overline{\boldsymbol{X}}$ & $\mathbf{x}^{2}$ & $\mathbf{u}$ & $\mathbf{P}$ & $\bar{X}$ & $\mathbf{X}^{2}$ & $\mathbf{u}$ & $\mathbf{P}$ \\
\hline \multirow[t]{2}{*}{ Cinsiyet } & Erkek & 3.57 & - & 68328 & 0.095 & 3.70 & - & 51902 & 0.508 & 3.65 & - & 52147 & 0.374 & 3.48 & - & 53995.5 & 0.815 \\
\hline & Kadın & 3.47 & & & & 3.65 & & & & 3.69 & & & & 3.50 & & & \\
\hline \multirow[t]{4}{*}{ Yaş } & $18-25$ & 3.50 & 5.522 & - & 0.137 & 3.74 & 8.126 & - & 0.043 & 3.74 & 4.872 & - & 0.181 & 3.26 & 4.097 & - & 0.251 \\
\hline & 26-33 & 3.48 & & & & 3.56 & & & & 3.58 & & & & 3.45 & & & \\
\hline & $34-41$ & 3.55 & & & & 3.71 & & & & 3.66 & & & & 3.60 & & & \\
\hline & 42 ve üstü & 3.73 & & & & 3.94 & & & & 3.86 & & & & 3.46 & & & \\
\hline \multirow[t]{2}{*}{ Pozisyon } & Yönetici/Üst & 3.85 & - & 43914.5 & 0.001 & 3.92 & - & 33829 & 0.016 & 3.97 & - & 32750 & 0.003 & 3.79 & - & 32653 & 0.002 \\
\hline & Yönetici/Orta & 3.48 & & & & 3.64 & & & & 3.61 & & & & 3.42 & & & \\
\hline \multirow[t]{5}{*}{ Gelir } & 2000 TL ve aşağı & 3.44 & 7.625 & - & 0.106 & 3.57 & 4.099 & - & 0.393 & 3.51 & 13.796 & - & 0.008 & 3.31 & 18.792 & - & 0.001 \\
\hline & $2001-3000 \mathrm{TL}$ & 3.56 & & & & 3.75 & & & & 3.71 & & & & 3.52 & & & \\
\hline & $3001-4000 \mathrm{TL}$ & 3.71 & & & & 3.81 & & & & 3.88 & & & & 3.81 & & & \\
\hline & $4001-5000 \mathrm{TL}$ & 3.71 & & & & 3.85 & & & & 4.04 & & & & 3.83 & & & \\
\hline & 5001 TL ve üstü & 3.74 & & & & 3.80 & & & & 3.77 & & & & 3.53 & & & \\
\hline \multirow[t]{5}{*}{ Eğitim } & ilköğretim & 3.57 & 63.97 & - & 0.000 & 3.79 & 27.489 & - & 0.000 & 3.88 & 48.356 & - & 0.000 & 3.31 & 71.826 & - & 0.000 \\
\hline & Lise & 3.39 & & & & 3.41 & & & & 3.25 & & & & 3.09 & & & \\
\hline & Ön lisans & 2.80 & & & & 3.24 & & & & 3.13 & & & & 2.73 & & & \\
\hline & Lisans & 3.73 & & & & 3.84 & & & & 3.85 & & & & 3.73 & & & \\
\hline & Lisansüstü & 3.41 & & & & 3.64 & & & & 3.86 & & & & 3.61 & & & \\
\hline \multirow[t]{4}{*}{ Görev süresi } & $0-5$ yıl & 3.44 & 12.098 & - & 0.007 & 3.54 & 18.478 & - & 0.000 & 3.58 & 11.471 & - & 0.009 & 3.34 & 18.741 & - & 0.000 \\
\hline & 6-10 yıl & 3.57 & & & & 3.72 & & & & 3.54 & & & & 3.57 & & & \\
\hline & $11-15$ yıl & 3.76 & & & & 3.94 & & & & 3.92 & & & & 3.79 & & & \\
\hline & 16 yıl ve üstü & 3.57 & & & & 3.83 & & & & 3.81 & & & & 3.35 & & & \\
\hline
\end{tabular}

$\overline{\bar{X}}$ :Aritmetik ortalama, $\mathrm{X}^{2}$ : Ki-kare değeri, U:Mann-Whitney değeri, P:Anlamlılık düzey 
Öğrenen Organizasyon Boyutları

Sistemler Arası İletişim

Destekleyici Liderlik

Güçlendirilmiş Çalışanlar

\begin{tabular}{|c|c|c|c|c|c|c|c|c|c|c|c|c|c|}
\hline & & $\bar{X}$ & $x^{2}$ & $\mathbf{U}$ & $\mathbf{P}$ & $\bar{X}$ & $x^{2}$ & $\mathbf{U}$ & $\mathbf{P}$ & $\bar{X}$ & $x^{2}$ & $\mathbf{U}$ & $\mathbf{P}$ \\
\hline \multirow[t]{2}{*}{ Cinsiyet } & Erkek & 3.61 & - & 35901 & 0.375 & 3.43 & - & 52576 & 0.494 & 3.62 & - & 53916.5 & 0.760 \\
\hline & Kadın & 3.64 & & & & 3.45 & & & & 3.68 & & & \\
\hline \multirow[t]{4}{*}{ Yaş } & $18-25$ & 3.35 & 6.846 & - & 0.077 & 3.38 & 1.808 & - & 0.613 & 3.71 & 8.245 & - & 0.041 \\
\hline & $26-33$ & 3.60 & & & & 3.39 & & & & 3.51 & & & \\
\hline & $34-41$ & 3.64 & & & & 3.47 & & & & 3.70 & & & \\
\hline & 42 ve üstü & 3.80 & & & & 3.52 & & & & 3.79 & & & \\
\hline \multirow[t]{2}{*}{ Pozisyon } & Yönetici/Üst & 3.87 & - & 22980.5 & 0.010 & 3.83 & - & 29094 & 0.000 & 3.97 & - & 31490 & 0.000 \\
\hline & Yönetici/Orta & 3.57 & & & & 3.36 & & & & 3.57 & & & \\
\hline \multirow[t]{5}{*}{ Gelir } & 2000 TL ve aşağı & 3.37 & 33.187 & - & 0.000 & 3.25 & 20.949 & - & 0.000 & 3.51 & 12.722 & - & 0.013 \\
\hline & $2001-3000 \mathrm{TL}$ & 3.78 & & & & 3.49 & & & & 3.62 & & & \\
\hline & $3001-4000 \mathrm{TL}$ & 3.90 & & & & 3.73 & & & & 3.96 & & & \\
\hline & $4001-5000 \mathrm{TL}$ & 3.93 & & & & 3.71 & & & & 3.79 & & & \\
\hline & 5001 TL ve üstü & 3.60 & & & & 3.70 & & & & 3.93 & & & \\
\hline \multirow[t]{5}{*}{ Eğitim } & İlköğretim & 3.44 & 36.475 & - & 0.000 & 3.13 & 56.969 & - & 0.000 & 3.67 & 53.993 & - & 0.000 \\
\hline & Lise & 3.31 & & & & 3.10 & & & & 3.16 & & & \\
\hline & Ön lisans & 3.11 & & & & 2.89 & & & & 3.23 & & & \\
\hline & Lisans & 3.79 & & & & 3.65 & & & & 3.84 & & & \\
\hline & Lisansüstü & 3.89 & & & & 3.64 & & & & 3.62 & & & \\
\hline \multirow[t]{4}{*}{ Görev süresi } & $0-5$ yıl & 3.51 & 10.174 & - & 0.017 & 3.36 & 6.487 & & 0.90 & 3.48 & 19.6 & - & 0.000 \\
\hline & 6-10 yıl & 3.71 & & & & 3.41 & & & & 3.67 & & & \\
\hline & $11-15$ yıl & 3.74 & & & & 3.62 & & & & 3.94 & & & \\
\hline & 16 yıl ve üstü & 3.73 & & & & 3.49 & & & & 3.68 & & & \\
\hline
\end{tabular}

$\overline{\bar{X}}$ :Aritmetik ortalama, $\mathrm{X}^{2}$ : Ki-kare değeri, U:Mann-Whitney değeri, P:Anlamlılık düzeyi 
Öğrenen organizasyon kavramı yedi boyut açısından incelendiğinde ise, bütün boyutların iyi düzeyde olmadığı sonucuna varılmıştır. En düşük değere sahip öğrenen organizasyon boyutu 3.43 ile sistemler arası bağlantı, en yüksek olan ise 3.69 ile diyalog ile öğrenme özelliğidir. Ayrıca yöneticilere, işletmenizde öğrenen organizasyon kavramının uygulanıp uygulanmadığı ve bu kavramın ne derece bilindiği hususunda sorular sorulmuştur. Analiz sonucunda mobilya sektöründe genel olarak öğrenen organizasyon kavramının uygulanmadığı bulunmuştur. Mobilya sektöründe çalışan yöneticilerin yaklaşık \%70'inin öğrenen organizasyon kavramı hakkında bilgi sahibi olmadığı belirlenmiştir.

Mobilya sektöründe faaliyet gösteren işletmeler, öğrenen organizasyon uygulamalarını bünyelerinde gerçekleştirdikleri ölçüde başarılı olacaklarını ve öğrenen organizasyonun çalışanların performanslarına olumlu etkiler yapacağını unutmamalıdır. Bunun için, eğitim ve gelişmeyi destekleyen, bilgi paylaşımının olduğu, sistem düşüncesine ve ödüllendirme sisteminin varlığı konusuna önem veren, ortak bir vizyona sahip olan, personeli her konuda güçlendiren ve yüksek düzeyde takım çalışması ve işbirliğine önem veren bir yönetim yapısını benimsemelidirler. Ayrıca, öğrenen organizasyon düşüncesinin önemli olduğunu mobilya firmalarına aktardığımız takdirde, karı artırma, ihracata yönelme, maliyetleri düşürme ya da verimliliği arttırma gibi farklı nitelikteki hedeflere ulaşmasında kolaylık sağlamasının yanında ülke ekonomisine de katkı sağlayacaktır.

\section{TEŞEKKÜR}

Bu çalışma Artvin Çoruh Üniversitesi Bilimsel Araştırma Projesi (BAP) kapsamında 2012.590.02.10 nolu kodla desteklenmiştir.

\section{KAYNAKLAR}

Basım H N, Meydan C H, Şeşen H (2009) Bireyin örgütsel adalet algısının iç girişimcilik davranışı ile ilişkisi: Kamuda bir araştırma, iktisat Işsletme ve Finans, 24 (274): 79-99
Braham B J (1998) Öğrenen bir organizasyon yaratmak (Çev. Tekcan A), Rota Yayıncılık, i̇stanbul

Bulutlar F (2003) Öğrenen örgüt unsurlarının ders kalitesi üzerindeki etkileri, İş-Güç Endüstri illişkileri ve İnsan Kaynakları Dergisi, 5 (1) http://www.ısguc.org

Çoban G (2006) Öğrenen organizasyon ve bankacılık sektöründeki uygulaması, Selçuk Üniversitesi Sosyal Bilimler Enstitüsü Yüksek Lisan Tezi, Konya

Diken A, Öztürk Y E, Çoban G (2006) Öğrenen organizasyon yaklaşımı ve Konya'daki banka organizasyonlarında ampirik bir araştırma, Selçuk Üniversitesi Karaman İktisadi ve İdari Bilimler Fakültesi Dergisi, 11 (9): 43-56

Diker I (2007) Öğrenen organizasyona geçiş sürecinde kurum kültürü, örgütsel engeller ve geçiş aşamaları (İstanbul tıp fakültesi örneği), Balıkesir Üniversitesi Sosyal Bilimler Enstitüsü Yüksek Lisans Tezi, Balıkesir, 13-16s.

Garvin A D (1993) Building a learning organization, Harvard Business Review, 7(14):78-91

Göztepe H (2009) Öğrenen organizasyon dinamiklerinin toplam kalite yönetimi, inovasyon ve organizasyon performansına etkileri, Gebze Yüksek Teknoloji Üniversitesi Sosyal Bilimler Enstitüsü Yüksek Lisans Tezi, Kocaeli

Güzelsoy E (2010) Organizasyonel öğrenmenin ürün inovasyonu üzerine etkileri, İstanbul Teknik Üniversitesi Fen Bilimler Enstitüsü Yüksek Lisans Tezi, İstanbul

İstar N (2006) Öğrenen organizasyonlarda başarı kriterleri ve bir uygulama, Yıldız Teknik Üniversitesi, Sosyal Bilimler Enstitüsü Yüksek Lisans Tezi, İstanbul

Özus E (2005) M.E.B. bağı Konya ilindeki mesleki ve teknik orta öğretim kurumlarında çalışan yönetici ve öğretmenlerin öğrenen organizasyonu algılamaları, Selçuk Üniversitesi, Sosyal Bilimler Enstitüsü Yüksek Lisans Tezi, Konya

Pedler M, Burgoyne J, Boydell T (1991) The learning company, Mc Graw-Hill, Newyork

Pelit E, Keleş Y, Çakır M (2010) Otel işletmesi iş görenlerinin öğrenen örgüt uygulamalarına ilişkin algıları: yerli ve yabancı zincir otel işletmelerinde bir araştırma, Organizasyon ve Yönetim Bilimleri Dergisi, 2 (2):59-68

Senge P (2004) Beşinci disiplin (Çev.İldeniz A, Doğukan A), Yapıkredi Yayıncılık, İstanbul

Tolgay F (2010) Öğrenen organizasyonlar ve bir uygulama, Bahçeşehir Üniversitesi Sosyal Bilimler Enstitüsü Yüksek Lisans Tezi, İstanbul, 33s

Tuna Ö, Çakırer M A (2008) Öğrenen organizasyon: Afyonkarahisar Kocatepe Üniversitesi, Ahmet Necdet Sezer Uygulama ve Araştırma Hastanesi'nin öğrenen organizasyon olma potansiyelinin incelenmesi, Afyon Kocatepe Üniversitesi İktisadi ve İdari Bilimler Fakültesi Dergisi, $X(2)$ : 257-272

Toylan, V N, Göktepe A E (2010) Öğrenen organizasyon olarak üniversiteler: Türkiye'deki bir devlet üniversitesinde durum analizi, Sosyal ve Beşeri Bilimler Dergisi, 2 (1): 61-68 
Watkins K, Marsick V (1997) Dimensions of the learning organization questionnaire (DLOQ): Participant's Guide for Interpreting Results. www.bus.colorado.edu/faculty/larsen/learnorg.html

Yazıcı S (2008) Öğrenen organizasyonlar, Alfa Yayıncılık, İstanbul
Yumuşak S, Yıldız H (2011) Eğitim örgütleri öğrenen organizasyon özellikleri göstermekte midir? Kamu ve özel ilköğretim okullarının Balıkesir ili örneğinde karşılaştırmalı bir analizi, İşletme ve Ekonomi Araştırmaları Dergisi, 2 (4): 159-177

Ek

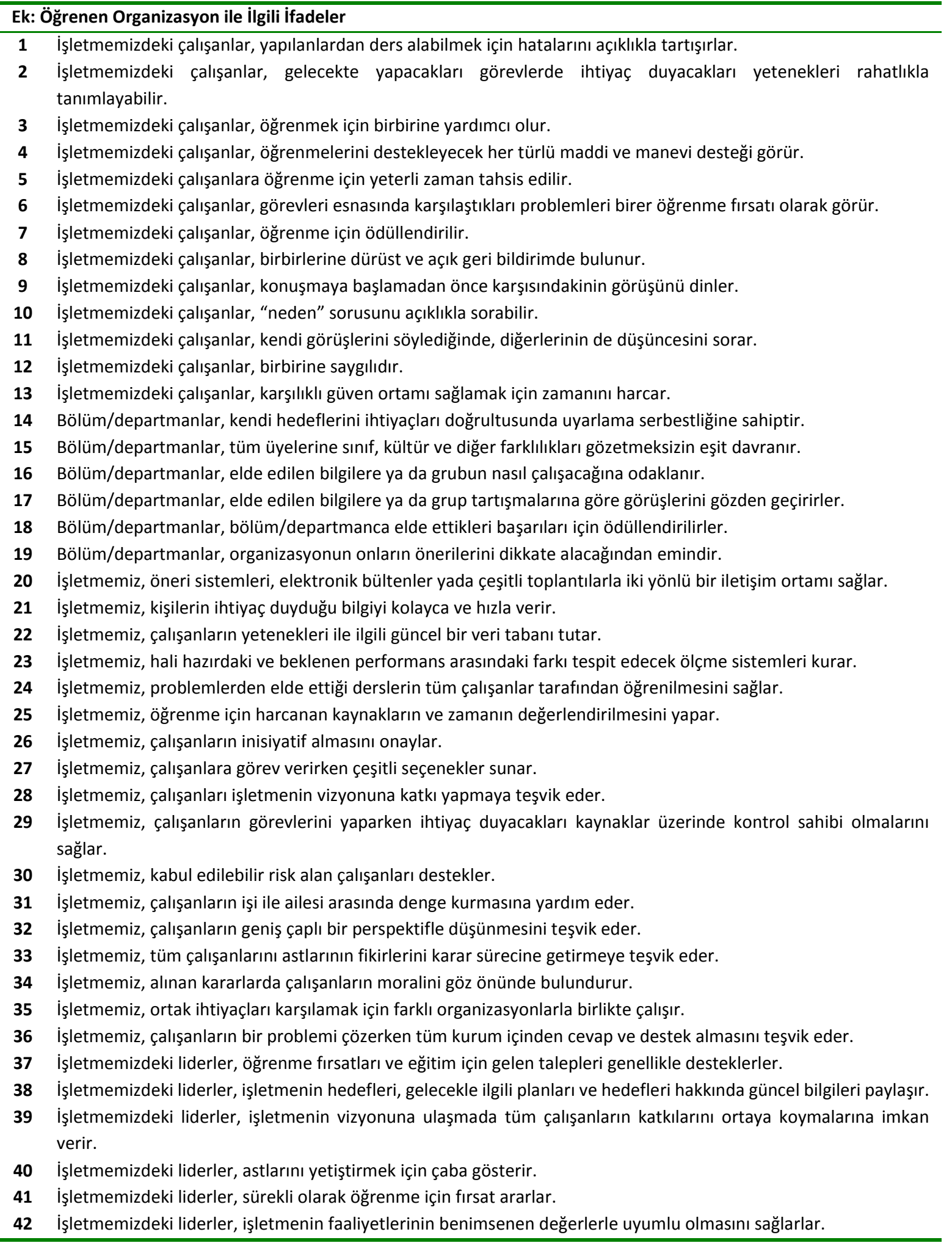

